可視化情報 Vol.20 Suppl. No.1（２００００７年７月）

\title{
The Mixing Ratio Extraction of Three Primary Colors on Picture Book
}

\author{
Noriko ISEDA ${ }^{\circ}$, Yuji MATSUMAE, Harumi IWASAKI, Yoshifuru SAITO, Kiyoshi HORII
}

Abstract

The colors on picture books by Dick Bruna have been analyzed by using computer.

Fundamental colors including red, blue and green specified by Bruna himself are revealed to be not pure fundamental colors. These picture books have taken reposeful colors that mixed one fundamental color to another fundamental one. The thread of narrative is made a development along the changes of these reposeful colors that increases the charm of picture books by Bruna.

Keyword; Primary color mixing ratio, Picture book, Narrative thread

1 はじめに

絵本は子ども読者の興味を引くよう、様々なエ夫を 凝らして制作されている。

特に絵本の色彩には、「緑は自然」、「青は勂」など象 徽的な意味を持たせることが多く、作家の心象に依存 する特有の色情報が内在している。

一般的に、豊富な色彩は華やかさを与え、青い空と 緑の芝生は健康的なすがすがしさを感じさせる。この ように、色によって人々の心に訴えることが出来るの は、色によって呼び起こされる人々の感情やイメージ に共通する部分が多いためといわれている。

C.E.Osgoodによって開発された Semantic Differential Method によれば、原色は怒り、娭妬、 环独など強い感情イメージを与え、混合色は萝、幸福、 郷愁など暖かい、優しい感情イメージを与えることが 明らかになっている。1)

本論文では、鮮やかな色彩と単純な図柄で、見る者
に安心感・想像力・夢を与え、世界中の子どもに愛さ れている、オランダの絵本作家ディック=ブルーナの 『うさこちゃん』シリーズ（福音館書店, 1964 年）を 解析対象にした。ブルーナ作品は一見鮮やかな原色が 使われているようにみえるが、優しさと暖かさが子ど も読者に伝わってくるといわれていることから、筆者 等は混合色ではないかと推定した。

そこで本論文の目的は、ブルーナ絵本の色彩におけ る RGB 混合率、子どもへの心理学的影響を明らかにす ることにある。具体的には、ブルーナの絵本に使用さ れた色彩に注目し、各場面のイラストの色彩が持つ、 視覚的に識別できない固有の混合色情報を、コン ピュータで可視化し、推論を客観化することを試みた。 また、ストーリーの展開による文章から読みとれる情 報と、色の配分や用いられ方の変化からの色情報を抽 出することで、文畵情報と色情報の比較検討を行った。 


\section{2 桧本の色彩 RGB 湦合事}

絵本画像の中の不変量を、斎藤により提案され2)斎 藤らによって発表された 3）「自然界の固有值に対応さ せて、画像情報の持つ不変量をコンピュータによって 固有值を抽出する解析方法」を応用することをファイ ナルゴールに、今回はその第一段階として色の混合率 を抽出することを試みた。

この方法は、計算機の $\mathrm{x}, \mathrm{y}$ 直交座標上に表わされた、 画像データの画素数、画像の $\mathrm{x}, \mathrm{y}$ 座標上の位置、角度 などに依存する性翼を削除し、画像本来の性翼を抽出 する R (赤) G（緑） B（青）直交座標を考え、この 3 次元直交座標上に $\mathrm{x}, \mathrm{y}$ 座標上の原画像を投影すること で、画像の RGB の混合率を抽出するものである。

ここでは、画像から RGB の混合率を抽出する概念を 述べる。

コンピュータグラフィックスで表現される画像は、 スクリーンの $\mathrm{x}, \mathrm{y}$ 直交座標上の R. G. B 画素の組み合わ せである。すなわち、m.n をそれぞれ $\mathrm{x}, \mathrm{y}$ 方向の画素 数とすれば、

$$
\begin{aligned}
& {\text { image } \in \text { pixcel }_{i, j},}_{\text {pixcel }_{i, j} \in f_{r}\left(x_{i}, y_{j}\right), f_{g}\left(x_{i}, y_{j}\right), f_{b}\left(x_{i}, y_{j}\right),} \\
& i=1,2, \ldots m \\
& j=1,2, \ldots n
\end{aligned}
$$

(1) 式で、 $f_{r}, f_{g}, f_{b}$ は、それぞれ、R, G, B 成分を与え る関数であり、（2）式の条件を满足する。

$$
\begin{aligned}
& 0 \leq f_{r}\left(x_{i}, y_{j}\right) \leq 1, \\
& 0 \leq f_{g}\left(x_{i}, y_{j}\right) \leq 1, \\
& 0 \leq f_{b}\left(x_{i}, y_{j}\right) \leq 1, \\
& i=1,2, \ldots m \\
& j=1,2, \ldots n
\end{aligned}
$$

（1）式で画像は画素の集合で表現され、画素は $\mathrm{x}, \mathrm{y}$ 座標上の関数で表現されるが $\mathrm{R}, \mathrm{G}, \mathrm{B}$ 直交座標を 考え、この 3 次元直交座標上で画像が表現されると する。すなわち、

$$
\begin{aligned}
& \text { image } \in g\left(r_{o}, g_{p}, b_{q}\right), \\
& r_{o} \in f_{r}\left(x_{i}, y_{j}\right), \\
& g_{p} \in f_{g}\left(x_{i}, y_{j}\right), \\
& b_{q} \in f_{b}\left(x_{i}, y_{j}\right), \\
& o=1,2, \ldots R \\
& p=1,2, \ldots G \\
& q=1,2, \ldots B, \\
& i=1,2, \ldots m \\
& j-1,2, \ldots n
\end{aligned}
$$

（3）式の形で画像は表現できる。ここで（3）式 中の o, p, q はそれぞれ R, G, B を最大值とする整数で ある。また関数 $g\left(r_{o}, g_{p}, b_{q}\right)$ は、

$$
\begin{aligned}
& 0 \leq\left|g\left(r_{o}, g_{p}, b_{q}\right)\right| \leq 1, \\
& o=1,2, \ldots R \\
& p=1,2, \ldots G \\
& q=1,2, \ldots B
\end{aligned}
$$

を満足するものとする。ここでは関数 $g\left(r_{o}, g_{g}, b_{q}\right)$ の 初期值はすべてぜロとし、座標值 $\left(r_{o}, g_{g}, b_{q}\right)$ が与え られるごとに関数値は

$g\left(r_{o}, g_{g}, b_{q}\right)=g\left(r_{o}, g_{g}, b_{q}\right)+1$

と加算され、すべての座標値について投影する。

(5)式で計算した結果を全ピクセル数で正規化する。

$$
\begin{aligned}
& \frac{\left\lfloor R_{i} G_{j} B_{k}\right\rfloor}{\sum_{i, j, k}^{10} R_{o} G_{p} B_{q}} \\
& i, j, k=1,2, . .10
\end{aligned}
$$

\section{3 絵本の解析方法ならびに結果}

フルーナの絵本は、 $15.5 \times 15.5$ の正方形のイラス ト 12 枚で棈成されていて限られた 6 色しか使用されな い。この解析では、正方形のイラストを背景色も含め 
て一つの画像と見なし、シリーズ 4 冊の絵本から画像 を解析して比較した。

\section{1 解析手順}

解析手順は以下の 3 つのプロセスをふむ。 (1)スキャナーでコンピュータに画像データを取り 込む。

(2)2 の手法によりピクセルごとの RGB 混合率を計算 をする。

(3)解析結果を 3 D グラフ上に可視化する。

\section{2 解析結果}
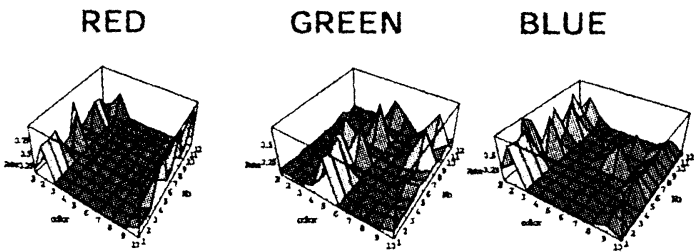

『ちいさなうさこちゃん』

FIG.1

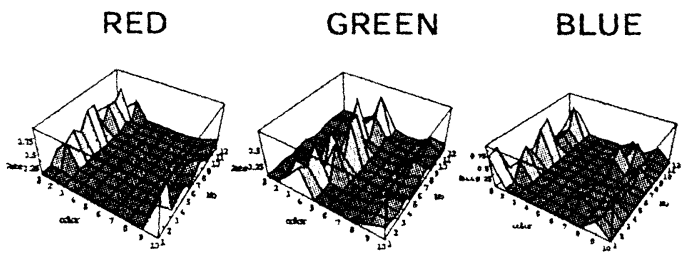

『うさこちゃんとどうぶつえん』

FIG.2

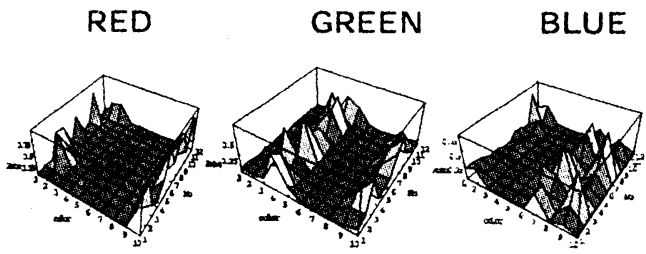

『ゆきのひのうさこちゃん』

FIG.3

RED

GREEN

BLUE

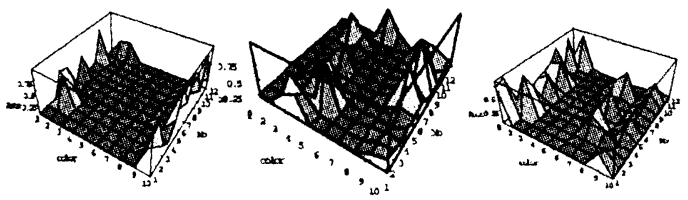

『うさこちゃんとうみ』

FIG.4
FIG. 1-4 はグラフは 4つの物語のイラストの色彩を RGB ごとに分けて抽出し解析した結果である。一冊の 絵本を 1 ページ目から順に解析してストーリーの流れ を追っている。

図の横軸は各色の憼淡レベルを示し奥から手前に いくにしたがって、色の度合いが淡くなる。高さは一 枚の絵が占めている色の頻度（ピクセルの個数）を示 す。縌軸はストーリー展開を表わし、奥に向かうにし たがってストーリーが進んでいく。

例えば FIG.4 は青を背景にした海水浴に行く話で ある。この絵では始めから 4 枚日の絵で海の場面が出 てくるために、BLUE のグラフの 4 番目で頻度が高く なっている。

また、FIG. 3 は雪の日の話で寒さをイメージする青 成分の色が効果的に使われているため、物語の始めか ら青色の頻度が高い。

グラフの右端のレベルをすべて総合すると白色に なる。これは画像を取り込むときの光の三原色による。

このグラフから、ブルーナの絵本を目で見たところ は原色を使っているように見えるが、RGB に分解する と、実は明るめではなく落ち着きのある暗めの RGB 混 合色が使われていることが分かった。すなわち読み手 に慗張感ではなく、安心感を与える色彩を使用してい る。

FIG. 1 と FIG. 2 は物語の始めから終わりまでの GREEN の色の潾さがほぼ同じであることが分かる。 BLUE の隆起の傾向もよく似ている。FIG. 1 と FIG. 2の物語は、ストーリーに連続性はないがページごと に絵に登場する人物が変化する。物語の終盤で BLUE が FIG. 1 と FIG. 2 とも緩やかに隆起しているのが特 徴である。

FIG. 3 とFIG. 4 は起承転結がありストーリ一的に似 ているが、GREEN のグラフもほ活似た傾向を示してい る。ここからは、ストーリーの展開は、私たちの一番 印象に残る赤成分ではなくて、緑成分と青成分を主に 用いることによって構成されていることがグラフの隆 起部分から予測できる。

FIG. 3 の GREEN のグラフからは、粶色と青色は物語 の中で交互に効果的に使われていることが分かる。

\section{4 考塞}

4. 1 ブル一ナ絵本の基本色と混合色について

ブルーナの絵本で使われる色は 6 色だけで、それぞ れの色にはブルーナ本人の象徵的イメージとしての位 置づけがある。5) 


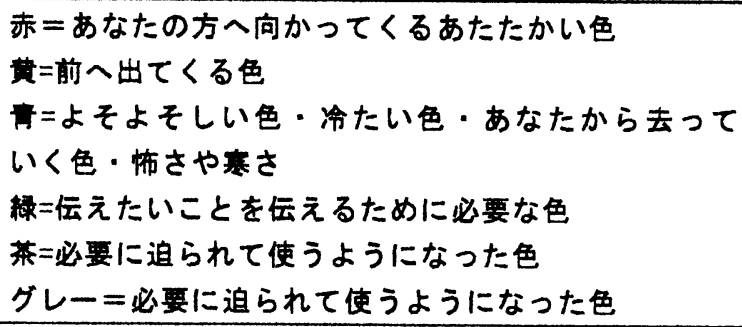

色彩心理学の見地からは、色に対して持つイメージ は、一般的にある程度パターン化されており、またそ の精神状態などにより色彩の好みも変わってくるとい われている。象徽語の持つイメージを色で表した統計 によると、例えば幸福=ピンク、家庭=黄緑、曹＝ピン クといったように、混合色は柔らかく温かいイメージ を抱かせる。4)

解析結果によれば、ブルーナの絵本もまた、鮮やか な原色で描かれているように見えても、実はいくつか の色を混ぜ合わせて作られた混合色であり、落ち着い た暗い色彩を用いていたことが判明した。例えば、ブ ルーナのいう青は、よそよそしい色・冷たい色・あな たから去っていく色・怖さや寒さの象徴としているが、 解析結果からはブルーナの青は、単なる冷たさを表現 する青ではなく、多くの暖色系の色が混ざっているこ とが分かる。

限られた色しか使わないことで、可視化された色の 背後にある色のメッセージこそブルーナカラーの特徴 であると思われる。

また、ストーリーの置かれた状況によって色の頻度 も違い、色を微妙に使い分けていることが判明した。 例えば、安心感や安らぎ、家族愛はブルーナの絵本の 場合には緑色成分で構成されていることが多い。フ ルーナの緑に対するイメージは「伝えたいことを伝え るために必要な色」とあり、心理学でいう「家庭＝黄 緑」と通じるものがある。

青色の後に、緑色が出てくることで子ども読者にも安 心感が与えられる。

これらの混合色を使用したことが、ストーリーとイ ラストのイメージの共有を子ども誖者に容易にさせて いる。この点こそがブルーナの絵本の魅力となってい るのではないだろうか。

\section{5 結贯}

ブルーナ絵本における色彩情報の固有値を抽出した 結果以下のようなことが明らかになった。

（1）ブルーナ絵本に使用された色彩は可視化情報とし ては「ブルーナカラー」といわれている 6 原色である が、視覚的に識別しにくい比較的落ち着いた色調の混 合色情報を保有することが分かった。

(2) ストーリーの展開による文章から読みとれる情報
と、色の配分や用いられ方の変化からの色情報を抽出 することで、文畫情報と色情報の相関があることが予 測された。

\section{使用テキスト}

FIG『ちいさなうさこちゃん』

FIG2『うさこちゃんとどうぶつえん』

FIG3『ゆきのひのうさこちゃん』

FIG4『うさこちゃんとうみ』

ディック・ブルーナ/石井桃子訳 （福音館書店 1964）

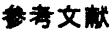

1) 江森康文 大山正 深尾謹之介『色その科学と文化』(朝 合書店 1979)

2) 䡃藤兆古『Mathematicaによる画像処理入門』(朝會書店 1998)

3)若林健一 早野誠治 莎藤兆古 國井利泰 堀井清之 传久問正用

「画像の固有パターンと磁界分布解析への応用」

（法政大学計算科学センター研究報告 13.69-73 2000)

4)C.Gミューラー/立石嶰勏『感觉心理学』

(岩波書店 1966)

5）『ディック・フルルーナのすへてて』講談社編 1999

6)特許「離散ウェーブレット変換を用いた推定方法」特開平 $11-39286$

7)特許「文学作品解析方法および解析装膡」特願 10-102673

Contributed Part to this Paper

Noriko Iseda

Picture Book Analyzing

Yuji Matsumae

Advice for Picture Book Selection

Harumi Iwasaki

Saito Theory Modification for Applying Picture Book Yoshifuru Saito

Originator for Eigen Pattern of Graphic Image called Saito Theory

Kiyoshi Horii

Liaison Concept Proposal between Literature and Saito Theory 